\title{
Developing early readers: Patterns in introducing critical reading skills and strategies to South African children
}

\author{
Authors: \\ Celeste Combrinck ${ }^{1}$ \\ Surette van Staden ${ }^{2}$ \\ Karen Roux ${ }^{1}$ \\ Affiliations: \\ ${ }^{1}$ Centre for Evaluation and \\ Assessment, Department \\ of Science, Mathematics \\ and Technology Education, \\ University of Pretoria, \\ South Africa \\ ${ }^{2}$ Department of Science, \\ Mathematics and Technology \\ Education, University of \\ Pretoria, South Africa \\ Correspondence to: \\ Surette van Staden \\ Email: \\ surette.vanstaden@up.ac.za \\ Postal address: \\ c/o George Storrar and \\ Leyds Streets, Pretoria 0002 \\ South Africa \\ Dates: \\ Received: 10 Dec. 2013 \\ Accepted: 19 May 2014 \\ Published: 14 Nov. 2014 \\ How to cite this article: \\ Combrinck, C., Van Staden, S. \\ \& Roux, K., 2014, 'Developing \\ early readers: Patterns in \\ introducing critical reading \\ skills and strategies to \\ South African children', \\ Reading \& Writing 5(1), Art. \\ \#45, 9 pages. http://dx.doi. \\ org/10.4102/rw.v5i1.45

\section{Copyright:} \\ (C) 2014. The Authors. \\ Licensee: AOSIS \\ OpenJournals. This work \\ is licensed under the \\ Creative Commons \\ Attribution License. \\ Read online:

This study draws on the preProgress in International Reading Literacy Study (prePIRLS) 2011 data. It aims to illustrate the effect of early home literacy activities and the early introduction of reading skills and strategies in the school setting on reading literacy achievement amongst South African Grade 4 learners across the 11 official languages. South African learner performance is consistently poor across a variety of international assessment programmes. The prePIRLS 2011 study results place South African Grade 4 learners' results substantially below the international centre point of 500 at 461 (SE = 3.7). As part of the reading achievement assessment, prePIRLS 2011 gathered background information in the form of learner, parent, teacher and school questionnaires. This study investigates two aspects as reported by parents and school principals of Grade 4 learners: firstly, parents of Grade 4 learners reported in the Learning to Read survey (or Parent Questionnaire) on the frequency with which early home literacy activities were conducted in the home before the learner commenced schooling. Secondly, principals of learners reported on the grade level (from Grade 1 to Grade 4 and beyond) at which a number of critical reading skills and strategies were introduced to learners. Fourteen such skills are identified, ranging from basic skills to skills with increased complexity. This study links the frequency of early home literacy activities, as reported by Grade 4 learners' parents, and the introduction of the 14 reading skills, as reported by school principals, to learner achievement scores in the prePIRLS 2011 assessment.

\section{Introduction}

A universally accepted goal of primary education is the mastery of reading comprehension, since reading comprehension provides the basis for most learning that takes place in secondary school (Sporer, Brunstein \& Kieschke 2009). This study aims to illustrate the link between the introduction of early home literacy activities as well as reading skills and strategies early in the Foundation Phase to aid the development of comprehension and thus reading literacy achievement amongst South African Grade 4 learners. In South Africa, grave concerns with regard to low levels of learner achievement pervade research initiatives and educational debates. Despite considerable investments in educational inputs (such as policy and resources) and processes (such as curriculum provision and teacher support), outcomes (in the form of learner achievement) remain disappointingly low. Despite national efforts, South African school learners have repeatedly been failing grades or leaving school, a trend that is reported by Taylor, Fleisch and Shindler (2008) in their review of educational changes in South Africa since 1994. Almost half of the learners who dropped out of the system did so due to a lack of basic learning skills, more specifically a lack of adequate language skills. Another reason for this high attrition rate can be attributed to child-headed families where parents are absent (Richter \& Desmond 2008): those learners who leave school prematurely no longer deem education as important when compared to basic needs; rather, they seek out work to support and provide for their family (MacLellan 2005).

South African learners' poor performance in reading literacy was first evidenced by the results of the Progress in International Reading Literacy Study (PIRLS) 2006. As an international comparative study, PIRLS is administered in five-year cycles and requires the assessment of learners who have had four years of schooling (Mullis et al. 2007). For most countries, this requirement translates to Grade 4 learners. PIRLS 2006 aimed to describe trends and international comparisons for the reading achievement of Grade 4 learners. It also focused on learners' competencies in relation to goals and standards for reading education, the impact of the home environment and how parents foster reading literacy, the implementation of the curriculum, time and reading materials for learning to read in schools and classroom approaches to reading instruction (Mullis et al. 2004).

The South African PIRLS 2006 study assessed a first population of Grade 4 learners, but also included a second population of Grade 5 learners as a national option within the study (Howie 
et al. 2009). South African Grade 5 learners achieved the lowest score of the 45 participating education systems with a score of 302 (SE = 5.6). Grade 4 learners achieved on average 253 points $(\mathrm{SE}=4.6)$. Average achievement for both these grades was well below the fixed international reference average of 500 points.

In PIRLS 2011, the South African study assessed a Grade 5 population in an attempt to develop trends from PIRLS 2006 to PIRLS 2011. However, to assess Grade 4 learners, South Africa opted to participate in the preProgress in International Reading Literacy Study (prePIRLS) 2011. Mullis et al. (2012) describe prePIRLS 2011 as a less difficult version of PIRLS which allows developing countries to assess children's reading comprehension with shorter texts, easier vocabulary, simpler grammar and less emphasis on higher-order reading skills. PrePIRLS is designed to test basic reading skills that are prerequisites for success in PIRLS (Mullis et al. 2012). South African Grade 4 learners were assessed across all 11 official languages.

PrePIRLS 2011 results point to continued underperformance by South African learners with little evidence of improved reading literacy scores, even when administering an easier assessment. The prePIRLS 2011 study results revealed that South African Grade 4 learners obtained 461 (SE = 3.7), the lowest reading achievement score in comparison with the international centre point of 500. In contrast, learners from Botswana achieved $463(\mathrm{SE}=3.5)$ and learners from Colombia obtained $576(\mathrm{SE}=3.4)($ Mullis et al. 2012).

A further breakdown of South African prePIRLS 2011 results reveal severe learner underperformance on international benchmarks. The prePIRLS 2011 scores provide information on learners' performance in reading achievement on a range of literary and informational texts (Mullis et al. 2012). For each of these texts, learners responded to questions that measure a series of comprehension skills, ranging from retrieval to inference and integration and evaluation. Achievement is reported at four points along a scale of international benchmarks and includes the Advanced International Benchmark with achievement at 625 points, the High International Benchmark with achievement at 550 points, the Intermediate International Benchmark with achievement at 475 points and the Low International Benchmark with achievement at 400 points. Achievement at the Low International Benchmark represents performance at basic reading levels.

Figure 1 illustrates South African Grade 4 learners' overall achievement on the international benchmarks ${ }^{1}$.

Figure 1 indicates that $42 \%$ of Grade 4 learners reached the Intermediate International Benchmark, with smaller percentages attaining the High International Benchmark

1.Benchmark scales are cumulative. The percentage of learners who did not attain the Low Internation the Low lnternational Ben Benchmark add up to $100 \%$. Of the $71 \%$ of South African Grade 4 learners who attained the Low International Benchmark, $42 \%$ attained the Intermediate International Benchmark, $18 \%$ the High International Benchmark and $6 \%$ the Advanced International Benchmark.

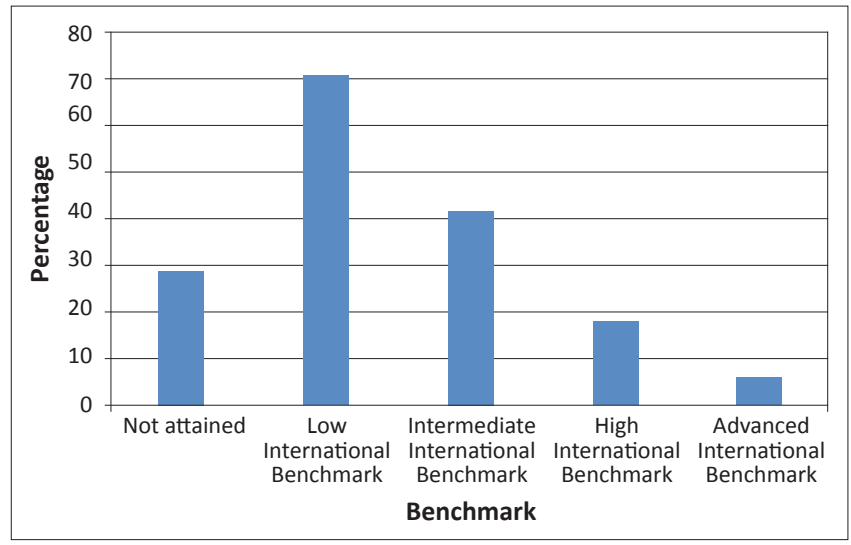

FIGURE 1: PrePIRLS 2011 overall benchmark results.

(18\%) and the Advanced International Benchmark (6\%) (Howie et al. 2012). Of concern is that as many as $29 \%$ of South African Grade 4 learners did not reach the Low International Benchmark in prePIRLS 2011, thereby being unable to provide evidence for having mastered basic reading skills. A majority of $71 \%$ of South African Grade 4 learners reached the Low International Benchmark (Howie et al. 2012). Attainment at this benchmark means that South African Grade 4 learners mostly have the ability to locate and retrieve explicitly stated detail in a literary text and the ability to locate and reproduce explicitly stated information from an informational text (Mullis et al. 2012). At this level, the majority of South African Grade 4 learners are unable to make straightforward inferences, integrate ideas and evidence across text or interpret events to provide reasons, motivations or feelings with full text-based support.

The home background is pivotal for learners' scholastic achievement and social development (Morrison \& Cooney 2001). Pretorius and Naude (2002) report on the everwidening gap in performance between children from rural or township backgrounds and children from affluent areas as an additional indicator of learners' poor reading skills. In the South African context, townships refer to those informal settlements, often found on the outskirts of urban areas, characterised by makeshift houses (or shacks). Townships are associated with lack of basic services (such as water and electricity supply), lack of resources and generally poor quality of schooling offered to children. Pretorius and Naude's research into the topic of poor reading and writing ability amongst children in South African townships found that only $36 \%$ of primary school children could take a book, turn it to the correct position and open it as if they were about to start reading from the book. Only $43 \%$ of children knew that words tell the story in a book. The researchers ascribe this shortcoming to a lack of books in the home, to parents or caregivers who themselves are illiterate and do not themselves have a culture of reading at home and to the lack of print-rich environments to which these children are exposed. Similarly, Dieden and Gustafson (2003) explore the roles of parents in urban and rural areas. They too claim that learners living in rural areas perform poorly since the parents are absent. 
Resources at home can be seen as essential for the development of reading literacy (Van Steensel 2006) and lack thereof may affect learners' performance in reading literacy. Conversely Mahery, Jamieson and Scott (2011) state that in more affluent areas, parents seem to live up to the expectations set out to assist their children with their literacy development needs. Other research has shown (Gonzalez-DeHass, Willems \& Holbein 2005; Hofferth \& Sandberg 2001; Sénéchal 2006) that parents who spend time on and actively make use of educational resources contribute to their children's literacy development, a situation that may be linked to learners' higher reading literacy achievement.

By implication, underachievement in reading literacy translates into unskilled readers who are limited in their metacognitive knowledge about reading. According to Mokhtari and Reichard (2002), unskilled readers do relatively little cognitive monitoring and tend to engage with reading as a decoding process rather than a meaning-making process. Unskilled readers are unlikely to detect contradictions in text, have trouble successfully resolving inconsistencies in understanding, exert little control of reading processes and are often unable to realise that they do not understand what is read (Mokhtari \& Reichard 2002). On the other hand, skilled readers from a young age demonstrate awareness of what they are reading, why they are reading, have tentative plans or strategies in place for handling potential problems and monitor their comprehension of textual information (Mokhtari \& Reichard 2002). Ricketts, Nation and Bishop (2007) provide additional evidence of learners with poor comprehension, who make up approximately $10 \%$ of children aged $7-11$ years old (Nation 2005). These learners have age appropriate reading skills, but have difficulty with reading comprehension specifically. Such learners may show strong phonological skills, but experience weaknesses in areas of language, such as listening, vocabulary and comprehending words with subtle inconsistent patterns in spelling and sound. Weaknesses in these areas tend to co-occur, meaning that children with limited vocabulary may inevitably struggle to comprehend words (Ricketts et al. 2007).

Taylor et al. (2000) place their work within effective schools and effective teaching traditions and conclude that effective teaching of reading strategies includes the use of small group instructional practices, coaching, systematic phonics instruction, higher-level questioning and balanced instruction on variables such as variable grouping patterns, support for reading, approaches to word recognition instruction, modes of learner interaction and practices to support text comprehension. Additionally, Taylor et al. (2000) list independent reading, involving parents in children's reading tasks and maintaining learner on-task behaviour as practices employed by effective reading teachers.

A distinction needs to be made between reading skills and reading strategies. Afflerbach, Pearson and Paris (2008) explain that these terms are either used interchangeably, as complimentary relations (where strategies support skills) or to denote developmental progression (where phonics skills are followed by comprehension strategies). Afflerbach et al. (2008) view reading skills as automatic actions that result in decoding and comprehension with speed, efficiency and fluency. Reading strategies, on the other hand, are deliberate, goal directed attempts associated with decoding text, understanding words and constructing meanings of text. Whilst Afflerbach et al. (2008) offer a useful distinction, reading skills and reading strategies will be used interchangeably for the purposes of this study to describe features of children's reading development as well as features of teachers' reading instruction.

\section{Research questions}

Based on the prePIRLS 2011 evidence of South African Grade 4 learners' poor overall reading literacy achievement and poor benchmark attainment, the following questions are asked:

1. How often do South African parents of preschool learners engage in early home reading activities?

2. When do critical reading skills and strategies first receive major emphasis in instruction at primary school?

3. How does the early introduction of and exposure to comprehension skills and strategies in the classroom interact with early home literacy activities to affect reading achievement scores?

\section{Method}

\section{Participants}

A nationally representative sample of 15744 Grade 4 learners from 342 schools participated in the prePIRLS 2011 study in South Africa. The sample consisted of 7548 girls and 8196 boys. Learners were assessed across all 11 official languages and were assessed in the Language of Learning and Teaching (LoLT) to which they were exposed in Foundation Phase. This means that learners were not necessarily tested in their home language, but rather in the language they were exposed to in school. The stratification by language resulted in the assessment of 1463 Afrikaans learners, 2205 English learners, 1393 isiNdebele learners, 1090 isiXhosa learners, 1209 isiZulu learners, 1099 Sepedi learners, 1431 Sesotho learners, 1293 Setswana learners, 2186 SiSwati learners, 1187 Tshivenda learners and 1188 Xitsonga learners.

\section{Data collection instruments}

Achievement tests: The prePIRLS 2011 assessment consisted of a reading literacy test in the form of two types of texts, namely reading for literary experience (or literary texts) and reading to acquire and use information (or informational texts). Reading texts were followed by a range of multiple choice questions and open response questions for a maximum of three points. Reporting of reading achievement results in prePIRLS 2011 are presented in terms of achievement above or below the fixed international centre point of 500 through the use of five overall plausible values ${ }^{2}$, as derived from item response analysis.

2.Plausible values consist of imputed values that were used during prePIRLS and PIRLS to estimate population characteristics accurately (Foy, Galia \& Isaac 2007). 
Background questionnaires: Grade 4 learners, their parents, teachers and school principals responded to contextual background questionnaires that addressed a wide range of topics on aspects such as reading behaviour, attitudes, teaching reading and school organisation. For the purposes of this study, responses from one set of items from the parent questionnaire and one set from the principal questionnaire were used. Parents of Grade 4 learners were asked how often they engaged with their child before they started school in a range of literacy activities on a Likert scale that included 'often', 'sometimes' and 'never'.

Principals were asked at which grade (Grade 1, Grade 2, Grade 3, Grade 4 or none of these grades) a range of reading skills and strategies first received major emphasis in instruction at their school.

Both the principal responses and the parent responses were converted to a scale and then to an index for further analysis.

Procedure: The International Association for the Evaluation of Educational Achievement (IEA) made the International Database Analyzer (IDB Analyzer) software available for the analysis of the PIRLS and prePIRLS datasets. This software was used for data analysis for the current investigation. Variables from the school and parent questionnaires were analysed to obtain descriptive statistics and percentages for response categories as reported by principals and teachers in conjunction with Grade 4 learners' overall reading literacy scores. The analysis resulted in percentage reports for principal and parent reports on the selected variables, with the expected effect on reading literacy achievement for each reported percentage.

\section{Results}

Means and percentages were used to gauge differences between groups. Firstly, the introduction of early home literacy activities was considered and the frequencies between parents who reported conducting these activities rarely, sometimes and often were examined. Mean reading achievement scores for different reported levels of conducting early home literacy activities were examined, as well as score-point differences between groups.

Secondly, frequencies of the grades in which school principals of Grade 4 learners reported that reading skills and strategies first receive major emphasis in their schools were examined. Cross-tabulations of grades in which reading skills and strategies first receive major emphasis and mean reading achievement scores were examined, as well as score-point differences between different grades of initial introduction.

Lastly, cross-tabulations of the early home literacy activities index and the principal index was created using IDB Analyzer.

Early home literacy activities: Figure 2 illustrates parents' reported frequency of conducting early home literacy activities with their child before they began school.

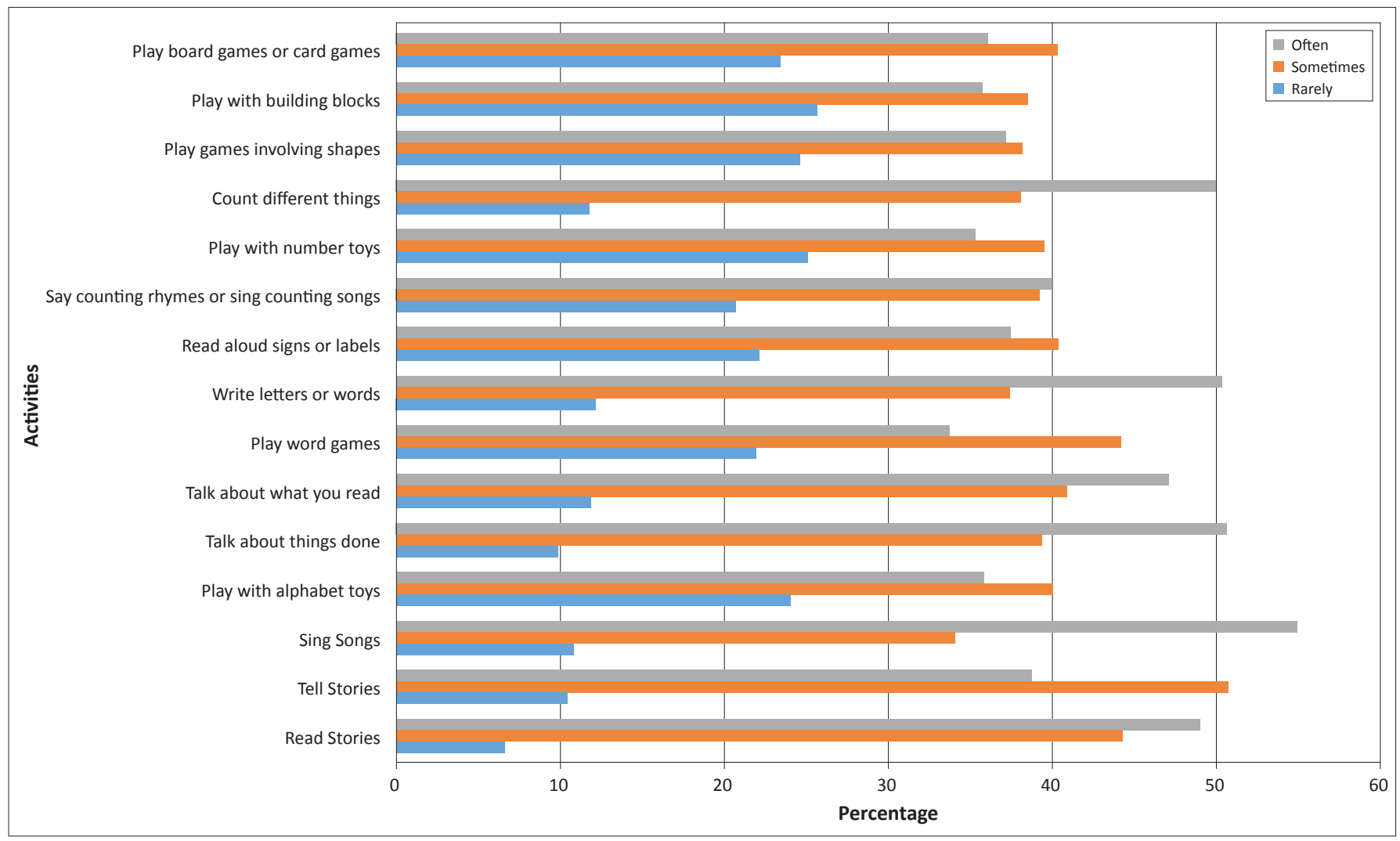

FIGURE 2: Frequency of early home literacy activities reported by parents. 
There are seven activities that $20 \%-25 \%$ of parents reported never or almost never engaging in with their child. Activities parents reported that they most rarely engaged in with their children include: Say counting rhymes or sing counting songs, Play word games, Read aloud signs or labels, Play board games or card games, Play with alphabet toys, Play games involving shapes, Play with number toys and Play with building blocks. The low frequency of these activities specifically may point to the absence of resources that would allow for these activities to take place. Typically, board games, cards, toys and alphabet toys are not widely available, especially in rural areas where a culture of activities with educational resources is not well established. The remaining activities, parents mostly reported conducting with their child either sometimes $(34 \%-55 \%)$ or often $(33 \%-54 \%)$.

Table 1 indicates that mean reading achievement scores can be expected to be higher when early home literacy activities are conducted by parents at least sometimes or often before the child commences school.

Reading achievement scores are higher for each of the early home literacy activities to which learners' parents responded without exception. For example, for the activity Tell stories, when the activity was conducted occasionally or often before commencing school, the mean reading achievement score was $471.87(\mathrm{SE}=4.69)$, whereas when this activity was conducted rarely or never, the score was $438.69(\mathrm{SE}=5.54)$.

Table 2 shows information on the score-point difference for reading achievement score in Grade 4 based on whether parents reported often engaging in the early home literacy activity or almost never engaging in the activity.

Differences in mean reading achievement scores are markedly affected by all the activities (scores 22.57 - 49.97), with two exceptions. Two literacy activities that do not make a large difference in learner achievement are Write letters or words (12.16 score difference) and Talk about what you read (5.97 score difference). The activity Play games involving shapes makes a difference of 49.7 points to the reading achievement score. The activities Say counting rhymes or sing
TABLE 1: Early home literacy activities means and percentages based on parents' reporting.

\begin{tabular}{|c|c|c|c|}
\hline Early home activity & $\begin{array}{l}\text { Reading achievement } \\
\text { score }\end{array}$ & $N$ & $\%$ \\
\hline \multicolumn{4}{|l|}{ Read stories } \\
\hline Occasionally or often & $466.99(4.34)$ & 11178 & 93.31 \\
\hline Rarely or never & $442.84(6.53)$ & 700 & 6.69 \\
\hline \multicolumn{4}{|l|}{ Tell stories } \\
\hline Occasionally or often & $471.87(4.69)$ & 10079 & 89.43 \\
\hline Rarely or never & $438.69(5.54)$ & 1156 & 10.56 \\
\hline \multicolumn{4}{|l|}{ Sing songs } \\
\hline Occasionally or often & $468.85(4.56)$ & 10046 & 89.07 \\
\hline Rarely or never & $445.69(4.64)$ & 1168 & 10.93 \\
\hline \multicolumn{4}{|l|}{ Play with alphabet toys } \\
\hline Occasionally or often & $473.29(4.83)$ & 8503 & 75.89 \\
\hline Rarely or never & $450.87(4.68)$ & 2647 & 24.1 \\
\hline \multicolumn{4}{|l|}{ Talk about things done } \\
\hline Occasionally or often & $469.71(4.37)$ & 10167 & 90.08 \\
\hline Rarely or never & $441.74(4.68)$ & 1025 & 9.92 \\
\hline \multicolumn{4}{|c|}{ Talk about what you read } \\
\hline Occasionally or often & $469.19(4.62)$ & 10042 & 88.05 \\
\hline Rarely or never & $460.45(5.71)$ & 1135 & 11.95 \\
\hline \multicolumn{4}{|l|}{ Play word games } \\
\hline Occasionally or often & $472.44(4.76)$ & 8718 & 78.02 \\
\hline Rarely or never & $451.72(4.97)$ & 2293 & 21.98 \\
\hline \multicolumn{4}{|l|}{ Write letters or words } \\
\hline Occasionally or often & $468.66(4.65)$ & 9973 & 87.77 \\
\hline Rarely or never & $458.16(6.06)$ & 1154 & 12.23 \\
\hline \multicolumn{4}{|c|}{ Read aloud signs or labels } \\
\hline Occasionally or often & $472.67(4.93)$ & 8656 & 77.81 \\
\hline Rarely or never & $454.48(4.21)$ & 2278 & 22.19 \\
\hline \multicolumn{4}{|c|}{ Say counting rhymes or sing counting songs } \\
\hline Occasionally or often & $475.71(4.83)$ & 8691 & 79.25 \\
\hline Rarely or never & $440.70(3.89)$ & 2283 & 20.75 \\
\hline \multicolumn{4}{|l|}{ Play with number toys } \\
\hline Occasionally or often & $475.10(4.90)$ & 8168 & 74.87 \\
\hline Rarely or never & $448.32(4.31)$ & 2762 & 25.13 \\
\hline \multicolumn{4}{|l|}{ Count different things } \\
\hline Occasionally or often & $471.23(4.69)$ & 9388 & 88.12 \\
\hline Rarely or never & $441.62(5.07)$ & 1267 & 11.88 \\
\hline \multicolumn{4}{|c|}{ Play games involving shapes } \\
\hline Occasionally or often & $477.32(5.09)$ & 8305 & 75.35 \\
\hline Rarely or never & $441.23(4.07)$ & 2646 & 24.64 \\
\hline \multicolumn{4}{|c|}{ Play with building blocks } \\
\hline Occasionally or often & $475.38(5.24)$ & 8084 & 74.26 \\
\hline Rarely or never & $449.93(4.50)$ & 2835 & 25.74 \\
\hline \multicolumn{4}{|c|}{ Play board games or card games } \\
\hline Occasionally or often & $477.71(4.97)$ & 7989 & 76.47 \\
\hline Rarely or never & $439.16(3.70)$ & 2989 & 23.53 \\
\hline
\end{tabular}

PrePIRLS reading achievement score $(M=500 ; S D=100)$

TABLE 2: Score-point differences based on frequency of early home literacy activities.

\begin{tabular}{llll}
\hline Early home literacy activity reported on by parents & $\begin{array}{l}\text { Reading achievement when often } \\
\text { engaged }\end{array}$ & $\begin{array}{l}\text { Reading achievement when rarely or } \\
\text { never engaged }\end{array}$ & Score-point difference \\
\hline Read stories & 472.28 & 442.84 & 29.44 \\
\hline Tell stories & 480.76 & 438.69 & 42.07 \\
Sing songs & 473.24 & 445.69 & 27.55 \\
Play with alphabet toys & 480.52 & 450.87 & 29.65 \\
\hline Talk about things done & 474.7 & 441.74 & 32.96 \\
Talk about what you read & 466.42 & 460.45 & 5.97 \\
Play word games & 474.29 & 451.72 & 22.57 \\
Write letters or words & 470.32 & 458.16 & 12.16 \\
Read aloud signs or labels & 479.17 & 454.48 & 24.69 \\
Say counting rhymes or sing counting songs & 484.19 & 440.7 & 43.49 \\
Play with number toys & 479.9 & 448.32 & 31.58 \\
Count different things & 478.88 & 441.62 & 37.26 \\
Play games involving shapes & 491.2 & 441.23 & 49.97 \\
Play with building blocks & 487.16 & 449.93 & 37.23 \\
\hline Play board games or card games & 479.56 & 439.16 & 40.4 \\
\hline
\end{tabular}


counting songs (43.49), Tell stories (42.07) and Play board games or card games (40.40) all make a large difference to reading achievement for those learners whose parents often engaged with them in such activities. In prePIRLS, a score of 40 points signifies a year of schooling. From these marked differences it would appear that early home literacy activities have an important impact on later literacy achievement.

\section{Introduction of reading skills and strategies in school context as reported by principals}

Descriptive statistics showed that certain reading skills and strategies in the principal questionnaire were underreported (i.e. few principals answered these questions) for introduction in early grades. To investigate why this may be the case, a review of the revised South African National Curriculum Statement (Department of Education 2002) for Grade R to Grade 9 was done in order to establish the extent to which the items that were asked of school principals were in alignment with the curriculum statement in use at the time of the prePIRLS 2011 study, as illustrated by Table 3 .

TABLE 3: Principal questions as classified by the curriculum statement.

\begin{tabular}{ll}
\hline Item as in school questionnaire & $\begin{array}{l}\text { Curriculum grade in } \\
\text { which to start activity }\end{array}$ \\
\hline Knowing letters of the alphabet & Grade 1 \\
Knowing letter-sound relationships & Grade 1 \\
Reading words & Grade R and Grade 1 \\
Reading isolated sentences & Grade 1 \\
Reading connected text & Grade 1 \\
Locating information within text & Grade 1 \\
$\begin{array}{l}\text { Identifying main idea of text } \\
\text { Explaining or supporting understanding of text }\end{array}$ & Grade 1 \\
Comparing a text with personal experience & Grade 3 \\
Comparing different texts & Grade 2 \\
\hline $\begin{array}{l}\text { Making predictions about what will happen next in a text } \\
\text { Making generalisations and drawing inferences based on a }\end{array}$ & Unclear \\
text & Grade 4 and beyond 4 and beyond \\
Describing the style or structure of a text & Grade 4 and beyond \\
Determining the author's perspective or intention & Grade 7 and beyond \\
\hline
\end{tabular}

Based on this classification of the items, only items that contain activities that should start in Grade 1 according to the revised curriculum were selected for analysis. This decision was taken as the majority of principals reported that these activities were taught in Grade 1, whereas later items were reported for higher grades in accordance with the curriculum guidelines. The first eight items were therefore investigated to establish if principals reported these activities for Grade 1 level and to investigate any under-reported activities that could possibly impact learner reading scores. Items that contain activities classified by the curriculum for higher grades were under-reported for lower grades; therefore, useful predictions based on these items could not be made due to small samples reporting such activities for Grade 1-3.

The grades in which school principals of Grade 4 learners reported that these reading skills and strategies first receive major emphasis in their schools is shown in Figure 3. These are the reading activities that should receive emphasis in Grade 1 according to the curriculum.

In excess of $75 \%$ of principals reported that basic reading skills (such as Knowing letters of the alphabet, Knowing lettersound relationships and Reading words) first receive emphasis in Grade 1 or earlier. Reading isolated sentences was reported by $56 \%(\mathrm{SE}=3.4)$ of principals as an activity that receives emphasis in Grade 1 or earlier. However, a steady decline in percentages is observed for the early introduction of skills and strategies such as Reading connected text $(31 \%, \mathrm{SE}=3.5)$ and Locating information within a text $(23 \%, \mathrm{SE}=3.4)$. Skills that require learners to Identify the main idea of a text $(21 \%, \mathrm{SE}=3.3)$ was hugely under-reported for first grade learners.

Table 4 provides information on how the early introduction of reading skills and strategies affects reading literacy

3.Small sample sizes reported for these activities resulted in large standard errors of the mean.

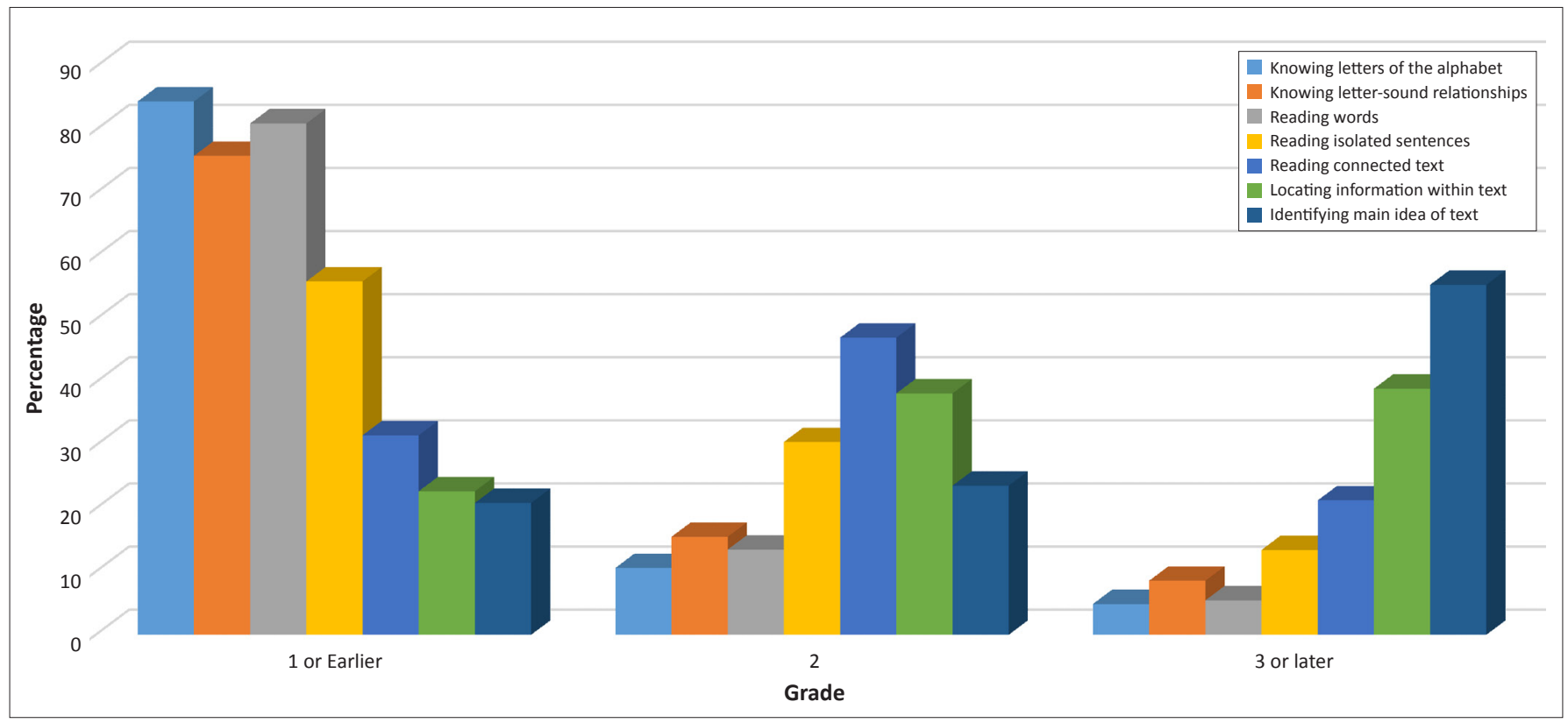

FIGURE 3: Grade by which reading skills and strategies first receive major emphasis. 
achievement scores in prePIRLS 2011. The items containing activities that should be taught in Grade 1 or earlier, as indicated by the revised national curriculum that was implemented in South African primary schools at the time of the prePIRLS 2011 study, are included.

Table 4 indicates that average reading achievement scores can be expected to be higher when specific reading skills and strategies are introduced in Grade 1 or earlier when compared to introduction of these skills and strategies beyond Grade 2. Reading achievement scores are higher for each of the reading skills and strategies to which learners' principals responded without exception. For example, the reading achievement score for item 4 (Reading isolated sentences) is $474.76(\mathrm{SE}=6.39)$ when the activity is begun in Grade 1 or earlier, but when the activity is begun in Grade 2 or later, the reading achievement score is 428.88 ( $\mathrm{SE}=8.04$ ).

Table 5 provides information on the score-point difference for each of the reading skills and strategies between their introduction at Grade 1 or earlier and their introduction in Grade 3 or later.

Score-point differences are most pronounced for Reading connected text (68.88 points), Locating information within text

\begin{tabular}{|c|c|c|c|}
\hline Activity with grade of implementation & $\begin{array}{l}\text { Reading achievement } \\
\text { score }\end{array}$ & $N$ & $\%$ \\
\hline \multicolumn{4}{|l|}{ Knowing letters of the alphabet } \\
\hline Grade 1/Earlier & $459.29(4.89)$ & 12174 & 84.53 \\
\hline Grade 2/Later & $432.83(17.98)$ & 2024 & 15.47 \\
\hline \multicolumn{4}{|l|}{ Knowing letter-sound relationships } \\
\hline Grade 1/Earlier & $463.87(4.84)$ & 10476 & 75.9 \\
\hline Grade 2/Later & $431.38(14.32)$ & 3652 & 24.1 \\
\hline \multicolumn{4}{|l|}{ Reading words } \\
\hline Grade 1/Earlier & $462.78(4.88)$ & 11096 & 81.04 \\
\hline Grade 2/Later & $424.87(15.93)$ & 3055 & 18.97 \\
\hline \multicolumn{4}{|l|}{ Reading isolated sentences } \\
\hline Grade 1/Earlier & $474.76(6.39)$ & 7558 & 55.99 \\
\hline Grade 2/Later & $428.88(8.04)$ & 6618 & 44.01 \\
\hline \multicolumn{4}{|l|}{ Reading connected text } \\
\hline Grade 1/Earlier & $493.71(10.13)$ & 3769 & 31.61 \\
\hline Grade 2/Later & $435.96(6.52)$ & 10109 & 68.39 \\
\hline \multicolumn{4}{|l|}{ Locating information within text } \\
\hline Grade 1/Earlier & $491.60(12.93)$ & 2658 & 22.74 \\
\hline Grade 2/Later & $445.49(6.84)$ & 11217 & 77.25 \\
\hline \multicolumn{4}{|l|}{ Identifying main idea of text } \\
\hline Grade 1/Earlier & $486.81(14.98)$ & 2009 & 20.9 \\
\hline Grade 2/Later & 453.59 (7.99) & 10911 & 79.1 \\
\hline
\end{tabular}

PrePIRLS reading achievement score $(M=500 ; S D=100)$.
(54.97 points) and Reading isolated sentences (54.65 points). On the prePIRLS 2011 average achievement scale, 40 points represents one year of schooling. As indicated in Table 7, the difference in scale score points for most of the activities translate to a difference of a year or more of schooling for those learners for whom the skill was introduced at Grade 1 or earlier in comparison to those learners for whom it was only introduced Grade 3 or beyond.

\section{Combined effect of conducting early home literacy activities and introducing four pivotal reading skills and strategies}

Figure 4 shows the effects of parents conducting early home literacy activities with their child before they begin school and introducing the four under-reported reading skills and strategies (Reading isolated sentences, Reading connected text, Locating information within text and Identifying the main idea of a text) in earlier grades.

Grade 4 learners who were in schools where the four reading skills and strategies were introduced in Grade 1, combined with parents who often conducted the early home literacy activities with them had a mean reading achievement score of 562.16 ( $\mathrm{SE}=14.43$ ). This average achievement is substantially higher than achievement for those learners who were in schools where these activities were only introduced in Grade 3 or later and who had parents who rarely or never conducted early home literacy activities with them. For these learners, mean reading achievement scores can be expected at only $432.20(\mathrm{SE}=10.53)$.

\section{Limitations}

The limitations of the current study mainly pertain to its reliance on self-report questionnaire data. When using self-

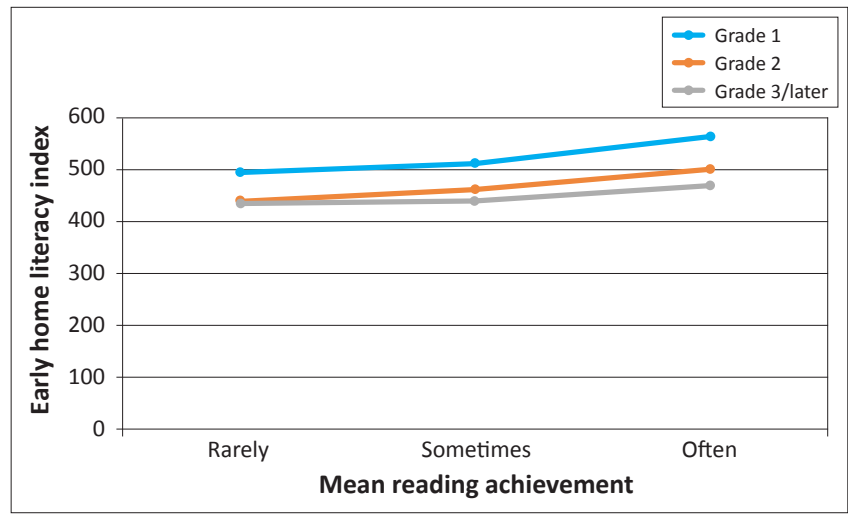

FIGURE 4: Effects of introducing the four neglected reading skills and strategies combined with parents conducting early home literacy activities.

TABLE 5: Score-point differences based on when skills are introduced.

\begin{tabular}{|c|c|c|c|}
\hline Activity & $\begin{array}{l}\text { Reading achievement when } \\
\text { introduced in Grade } 1 \text { or earlier }\end{array}$ & $\begin{array}{l}\text { Reading achievement when } \\
\text { introduced in Grade } 3 \text { or later }\end{array}$ & Score-point difference \\
\hline Knowing letters of the alphabet & 459.52 & 425.53 & 33.99 \\
\hline Knowing letter-sound relationships & 463.97 & 439.83 & 24.14 \\
\hline Reading words & 462.98 & 431.89 & 31.09 \\
\hline Reading isolated sentences & 474.8 & 420.15 & 54.65 \\
\hline Reading connected text & 494.33 & 425.45 & 68.88 \\
\hline Locating information within text & 492.98 & 438.01 & 54.97 \\
\hline Identifying the main idea of a text & 488.04 & 450.06 & 37.98 \\
\hline
\end{tabular}


report data, one runs the risk of using data with some aspect of social desirability in respondents' attempts to provide an overly positive image of themselves.

Principals reported on a variety of issues in the prePIRLS 2011 school questionnaire. It may be argued that principals are not accurately familiar with content being taught in the classroom. In this respect, principal responses to content questions could have been correlated with teacher responses from the teacher questionnaire if such analysis was aligned to the focus of the current study. If the prePIRLS 2011 study allowed for learner books to be examined, it could have provided a better indication of content being taught. However, prePIRLS 2011 took the form a survey study in which learner books did not form part of the methods employed. As a secondary analysis of data, the current study also could not employ learner books as part of its methods.

In attempts to increase the accuracy of parent responses, questionnaires were provided to parents in both English and the language in which the child was tested. In this way, parents could switch between languages when encountering difficulties in understanding questions.

Response options in survey questionnaire are often problematic, since reference to 'sometimes' and 'often' are highly subjective. In the current study it was attempted to capture patterns in the data by converting individual responses to scales in attempts to counter the effects of subjective response patterns. It has to be kept in mind that the nature of survey research provides data that remain proxies (or approximations) of reality. Nevertheless, it is seen as important for large-scale studies such as prePIRLS to collect information from schools, teachers, parents and learners to help ascertain the extent to which current research recommendations are being implemented and to capture the reported reality in schooling systems (Mullis 2002). Such reporting can also provide a springboard to further research.

\section{Discussion}

The current study utilised data from the South African prePIRLS 2011 study in an attempt to illustrate the combined effect of parental involvement in early home literacy activities and the early introduction of reading skills and strategies by schools as factors that contribute to higher attainment in reading literacy.

In this study, the delayed introduction of reading skills and strategies in the foundation phase was found for four critical reading skills and strategies, despite an indication in the curriculum that these activities should be introduced in Grade 1. These neglected reading skills and strategies are:

- reading isolated sentences

- reading connected text

- locating information within text

- identifying the main idea of a text.
The results of the data indicate that these reading skills and strategies should be introduced in Grade 1 for learners to achieve improved reading skills and, ultimately, higher reading achievement scores in studies such as prePIRLS 2011. The data also provide evidence that even when skills and strategies are entrenched as part of the national curriculum, these still do not receive emphasis. In this regard, schools play a pivotal role in ensuring the implementation of the curriculum to ensure learners have the best chance at sustained success and mastery.

This study illustrates how the early introduction of reading skills and strategies in turn interacts with early home literacy activities which, when conducted frequently by parents before the child starts school, have a positive effect on the child's reading achievement. It is of great importance that parents actively engage in early home literacy activities with their children, since they assist in the development of cognitive and linguistic skills, which in turn assist in learner reading achievement (see also Sénéchal \& LeFevre 2002).

In partnership with the school, children should be afforded as much as possible opportunity for practice (Afflerbach et al. 2008). Practice may help children to develop decoding skills, word recognition and understanding. Yet, practice may still not be enough, in which case metacognitive instruction about how and why to use strategies, scaffolded and guided practice can be effective in ensuring the child makes progress. Schools thus have the task of providing metacognitive instruction with explicit teaching practices. Teachers can explain, use and model reading strategies by breaking reading down for the learner in order for them to become aware of readings' parts, how they work together and combining such parts into the skilled performance of reading. The effects of parental involvement in early home literacy activities can be strengthened and reinforced through targeted opportunities for practice at school in attempts by teachers to adequately cover the prescribed curriculum.

Together, parents and schools have the responsibility to lay the foundations for reading in the first year of schooling. When both these interventions are in place, in other words schools start early with all seven Grade 1 reading skills and strategies and parents conduct early home literacy activities with their children, then the learner will have a higher chance of mastering reading skills that are pivotal for later learning.

\section{Acknowledgements Competing interests}

The authors declare that they have no financial or personal relationships that may have inappropriately influenced them in writing this article.

\section{Authors' contributions}

S.v.S. (University of Pretoria) served as co-national research coordinator for PIRLS 2011. C.C. (University of Pretoria) 
focused on the analysis of data, whilst S.v.S. and K.R. (University of Pretoria) provided the background, literature review and discussion for the article.

\section{References}

Afflerbach P., Pearson P.D. \& Paris S.G., 2008, 'Clarifying differences between reading skills and reading strategies', The Reading Teacher 61(5), 364-373. http://dx.doi org/10.1598/RT.61.5.1

Department of Education, 2002, 'Revised National Curriculum Statement Grades R-9 (2002)', Government Gazette 23406, vol. 443.

Dieden, S. \& Gustafson, B., 2003, 'Child poverty in South Africa: An assessment based on micro data for 1995', International Journal of Social Welfare 12, 326-338. $\mathrm{http}: / / \mathrm{dx}$.doi.org/10.1111/1467-9671.00287

Foy, P, Galia, J. \& Isaac, L., 2008, 'Scaling the data form the TIMSS 2007 mathematics and science assessments, in J.F. Olson, M.O. Martin, I.V.S. Mullis (eds.), TIMSS 2007 Technical Report: TIMSS \& PIRLS International Study Center, Boston College, Chestnut Hill.

Gonzalez-DeHass, A.R., Willems, P.P. \& Holbein, M.F.D., 2005, ‘Examining the relationship between parental involvement and learner motivation', Educational Psychology Review 17(2), 99-123. http://dx.doi.org/10.1007/ sducational Psycho

Hofferth, S.L. \& Sandberg, J.F., 2001, 'How American children spend their time', Journal of Marriage and Family 63(2), 295-308. http://dx.doi.org/10.1111/ j.1741-3737.2001.00295.x

Howie, S.J., Van Staden, S., Tshele, M., Dowse, C. \& Zimmerman, L., 2012, South African children's reading literacy achievement summary report, Centre for Evaluation and Assessment, Pretoria.

Howie, S.J., Venter, E., Van Staden, S., Zimmerman, L., Long, C., Scherman, V. et al., 2009, PIRLS 2006 summary report: South African children's reading literacy achievement, Centre or Evaluation and Assessment, Pretoria, South Africa.

MacLellan, M., 2005, Child headed households: Dilemmas of definition and livelihood rights, paper presented at the 4th World Congress on Family Law and Children's Rights, Cape Town, South Africa, viewed 24 July 2013, from http:// www.childjustice.org/docs/maclellan2005. pdf\#search $=\% 22$ childheaded $\% 20$ households $\% 22$

Mahery, P., Jamieson, L. \& Scott, K., 2011, Children's act guide for child and youth care workers, Children's Institute, University of Cape Town and National Association of Child and Youth Care Workers, Cape Town.

Mokhtari, K. \& Reichard, C.A., 2002, 'Assessing learners' metacognitive awareness of reading strategies', Journal of Educational Psychology 94(2), 249-259. http:// dx.doi.org/10.1037/0022-0663.94.2.249
Morrison, F.J. \& Cooney, R.R., 2001, 'Parenting and academic achievement: Multiple paths to early literacy', in S.L.R.J.G. Borkowski \& M. Bristol-Power (eds.), Parenting and the child's world: Influences on academic, intellectual, and socioemotional development, pp. 141-160, Lawrence Erlbaum, Mahwah.

Mullis I.V.S., 2002, Background questions in TIMSS and PIRLS: An overview, TIMSS and PIRLS International Study Center, Boston College, Chestnut Hill.

Mullis, I.V.S., Kennedy, A.M., Martin, M.O. \& Sainsbury, M., 2004, PIRLS 2006 assessment framework and specifications, TIMSS and PIRLS International Study Center, Boston College, Chestnut Hill.

Mullis, I.V.S., Martin, M.O., Foy, P. \& Drucker, K.T., 2012, PIRLS 2011 internationa results in reading, Boston College, Chestnut Hill.

Mullis, I.V.S., Martin, M.O., Kennedy, A.M. \& Foy, P., 2007, PIRLS 2006 international report: IEA's study of reading literacy achievement in primary schools, Boston College, Chestnut Hill.

Nation, K., 2005, 'Children's reading comprehension difficulties', in M.J. Snowling, C. Hulme \& M. Seidenberg (eds.), The science of reading: A handbook, pp. 248-265, Blackwell, Oxford. http://dx.doi.org/10.1002/9780470757642.ch14

Pretorius, E.J. \& Naude, H., 2002, 'A culture in transition: Poor reading and writing ability among children in South African townships', Early Child Development and Care 172, 439-449. http://dx.doi.org/10.1080/03004430214552

Richter, L.M., \& Desmond, C., 2008, 'Targeting AIDS orphans and child-headed households? A perspective from national surveys in South Africa, 1995-2005', AIDS Care 20(9), 1019-1028. http://dx.doi.org/10.1080/09540120701842738

Ricketts, J., Nation, K. \& Bishop, D.V.M., 2007, 'Vocabulary is important for some, but not all reading skills', Scientific Studies of Reading 11(3), 235-257. http://dx.doi. org/10.1080/10888430701344306

Sénéchal, M., 2006, 'Testing the home literacy model: Parent involvement in kindergarten is differentially related to Grade 4 reading comprehension, fluency, spelling and reading for pleasure', Scientific Studies of Reading 10(1), 59-87. http://dx.doi.org/10.1207/s1532799xssr1001 4

Sénénchal, M. \& LeFevre, J., 2002, 'Parental involvement in the development of children's reading skill: A 5-year longitudinal study', Child Development 73 445-460. http://dx.doi.org/10.1111/1467-8624.00417

Sporer N., Brunstein, J.C. \& Kieschke, U., 2009, 'Improving learners' reading comprehension skills: Effects of strategy instruction and reciprocal teaching', Learning and Instruction 19, 272-286. http://dx.doi.org/10.1016/j.learninstruc.2008.05.003

Taylor, N., Fleisch, B., \& Shindler, J., 2008, 'Changes in education since 1994', Higher Education 32, 3-5.

Taylor, B.M. Pearson, P.D., Clark, K. \& Walpole, S., 2000, 'Effective schools and accomplished teachers: Lessons about primary-grade reading instruction in lowincome schools', The Elementary School Journal 101(2), 121-165. http://dx.doi. income schools', The
org/10.1086/499662

Van Steensel, R., 2006, 'Relations between socio-cultural factors, the home literacy environment and children's literacy development in the first years of primary education', Journal of Research in Reading 29(4), 367-382. http://dx.doi. org/10.1111/j.1467-9817.2006.00301.x 